\title{
The Representation of Historical Trauma in the Graphic Novel Persepolis by Marjane Satrapi
}

\author{
Eman Mohammed Abdel-Hamid Ibrahim \\ Ph.D. Researcher \\ Department of English, Faculty of Arts - Minia University
}

\begin{abstract}
$\underline{\text { Abstract }}$
Persepolis (2007) is a graphic novel by the Iranian writer Marjane Satrapi that sheds light on a critical period of historical trauma in Iran during the Islamic revolution (1979) and the Iran-Iraq war (1980-1988). In order to have a better understanding of historical trauma, this paper uses Maria Yellow Horse Brave Heart's studies on historical trauma to trace the impact of historical trauma on a traumatized society. Persepolis is not only a graphic novel, but also a memoir, so it depends on memory as the starting point to tackle trauma. Using the graphic memoir deciphers the codes of the traumatized memory. Thus, this paper discusses the idea of traumatized memory in psychoanalysis and questions its precision in narrating events. Generally speaking, the graphic novel medium has been gaining great popularity and appeal worldwide, yet little is known about its value in depicting traumatic experiences. This paper suggests an interesting and important link between trauma and graphic novel. It seems that graphic novels are efficient forums to tackle trauma (e.g. historical trauma in this paper) because of their word-image mix that provides the author with the utmost modes of expressing vividly what the mind cannot put into words. This paper ends with highlighting the vital role played by graphic memoir in documenting Satrapi's personal trauma and Iran's historical trauma through backing up Satrapi's memory both verbally and visually. In addition, this paper analyzes the strategies that Satrapi used to heal her traumatic memory (i.e. remembering, narration, and satire) as well as the consequences that historical trauma has on three levels (i.e. the individual, the family, and the community).
\end{abstract}

Keywords: Graphic Novel, Historical Trauma, Persepolis, Marjane Satrapi

\section{Introduction}

The role of the image in conveying the meaning more easily and effectively is unquestionable. It is known that a picture is worth a thousand words. This sums up the value of graphic novels. The graphic novel is a literary medium that depends on the arrangement of words and images in a certain way to narrate a story. Though the graphic medium has historically been attached to funny and light stories, some authors begin to turn to it to tackle traumatic and serious events. This is due to the word-image mix that graphic novels offer which enables authors to depict traumatic events in depth and to document many historical events that remain long invisible to the public, making it more accessible before the reader.

The word "trauma" is originally a Greek word that means "wound." It is a medical term used to depict a bodily or psychic injury; especially one caused by an acute event. Though there is no clear-cut definition of the term "trauma", Cathy Caruth offers a precise definition of it saying, "a response, sometimes delayed, to an 
overwhelming event or events, which takes the form of repeated... hallucinations, dreams, thoughts or behaviors stemming from the event" (4).

Authors begin to use literature as an outlet to tackle trauma. Yet, the nature of traumatic memory contradicts with that of literature. Traumatic memories "lack verbal narrative and context; rather, they are encoded in the form of vivid sensations and images (Herman 38). These images keep chasing the traumatic person: "to be traumatized is precisely to be possessed by an image or event" (Caruth 5). In this respect, the traumatic person finds a great difficulty in articulating his/her traumatic experience by relying on words solely, so he turns to "nonverbal methods of communication, such as drawing or painting" (Herman 177). This is why graphic novels serve as influential tools of healing trauma; "a narrative that does not include the traumatic imagery and bodily sensations is barren and incomplete" (Herman 177). Graphic novels enable their authors to face their fears and seek an alternative outlet of their trauma. The word-image mix of graphic novels works on recreating the images in the memories of a traumatic person, whereas a purely verbal medium of literature fails to get a precise access to them. Graphic novels use images to express the "frozen and wordless quality of traumatic memories" (Herman 37).

Marjane Satrapi (22 November 1969) is an Iranian graphic novelist, film director, and a cartoonist. She was born in Rasht, Iran, but she grew up in Tehran in a middle-class Iranian family. Persepolis traces the life of Satrapi: both as a child and as an adult, during the historical traumas of the Islamic revolution and the Iran-Iraq war. This political upheaval forces Satrapi to travel to Austria, then she settles in Paris, France. Persepolis recalls her life both in Iran and in Vienna. Apart from Persepolis, Starapi wrote other graphic novels including: Embroideries (2005), Chicken With Plums (2006), Monsters Are Afraid of the Moon (2006), and The Sigh (2011).

This paper aims at analyzing the use of graphic memoir as a medium in documenting historical trauma. It also examines the idea of traumatic memory in psychoanalysis and the ways of healing traumatic memory. Finally, it discusses the profound impact of historical trauma in influencing the individual, the family, and the community.

\section{Theory}

Psychoanalysis is applied to this study so as to offer a better understanding of trauma and the way it functions. It is known that "psychoanalysis began as a theory of trauma" (Bohleber 329). It is notable to mention that trauma was originally diagnosed as hysteria and it was connected to religion and myth. A traumatic person who showed hysterical symptoms was considered to be punished by God for his/her sins. It was believed that this traumatic person was a witch and was burnt to death. Thus, the judgment was directed towards the patient, without investigating the cause. Jean-Martin Charcot (1825-1893) conquers this superstitious diagnosis of trauma by leading scientific studies. Through his studies, Charcot "had demonstrated that these symptoms were psychological, since they could be artificially induced and relieved through the use of hypnosis" (Herman 11). Charcot found out, through hypnosis, that most of these patients suffered from sexual abuses: rape accidents and parents abusing their children. These abuses affected the lives of the patients and resulted in the hysterical states. Thus, Charcot begins to conclude that 
trauma is the basis of hysteria in which "intense fright could produce the traumatic syndrome" (Young 19). After Charcot, Sigmund Freud (1856-1939) continued what Charcot had started.

Sigmund Freud is considered the father of psychoanalysis. He resumes Charcot's studies of hysteric people with traumatic lives. Freud claims that there is a protective layer or barrier in our minds that protects us from tragic events and shocks. In his essay "Beyond the Pleasure", Freud declared that the term traumatic can be used to describe, "any excitations from outside which are powerful enough to break through the protective shield" (23). In other words, after a traumatic event, this shield is breached and a kind of disruption takes place, resulting in causing acute bodily and psychic damages. Though the images that reflect some traumatic event remain precise in the mind of a traumatized person, they cannot be consciously accessed or recalled. In reality, the traumatized person tries to run away from these memories. Thus, these traumatic memories begin to haunt the person as a ghost, in the form of nightmares.

Freud begins to pay a real attention to trauma in response to World War 1 (1914-1918) because of its unique nature and its high causalities. Yet, trauma studies reach their peak in the aftermath of the Vietnam War (1955-1975), after witnessing psychological disturbances on the soldiers who returned from this war. The American Psychiatric Association in 1980 called these disturbances PTSD (post traumatic stress disorder). Symptoms of PTSD include, "combinations of depression, general anxiety disorder, panic disorder, and chemical substance use disorders" (Young 112). The historical events that have swept the world everywhere give rise to the study of historical trauma.

The fusion of trauma and history is called historical trauma. Historical trauma studies begin to emerge to comprehend the history of violence and torture practiced by some societies against their people. The most prominent theorists of trauma (e.g. Cathy Caruth, Dori Laub, Shoshana Felman, among others) offer studies on the interrelationship between trauma and history in which history is written by the blood and pain of others. Most of the work done on historical trauma has been conducted by Maria Yellow Horse Brave Heart (1953), a Native American social worker, an Associate Professor at Columbia University, and a mental health expert. Historical Trauma is defined by Brave Heart in her article "Gender Differences" as a "cumulative and collective emotional and psychological injury both over the life span and across generations, resulting from a cataclysmic history of genocide ... and other massive generational group trauma" (2). This definition clarifies the characteristics of historical trauma. First, it is a collective trauma, not an individually experienced trauma. It is a collective complex trauma inflicted on a group of people who share specific group identityethnicity, nationality, and religious affiliation (Brave Heart, "Wakiksuyapi" 245). Second, the impact of historical trauma is not limited to the life span of the traumatized people, but it is transmitted across generations through contact with traumatized families.

Brave Heart is best known for developing a model of historical trauma for American Indians (also known as Native Americans) Brave Heart focused in her study on an important massacre in the history of Native Americans; the Wounded Knee Massacre (1890). 
This carnage is named after the site that witnessed the conflict between Native Americans and the US forces. This conflict results in the death of several hundreds of men, women, and children from the Native American side. Brave Heart writes that in this massacre, Native Americans "were disarmed and then massacred . . . their bodies thrown into a mass grave" ("Wakiksuyapi" 246). Another issue that caused trauma was sending many of the Native American children to boarding schools, in order to be safe from the traumatic circumstances.

\section{Persepolis as a Memoir}

Persepolis is a memoir. Memoir differs from both autobiography and biography, since memoir is a reflection of one's life on a narrower scale than the former kinds. A memoir "is how one remembers one's own life while an autobiography is history, requiring research, dates, facts, double-checked" (Yagoda 3). While autobiography and biography depict the whole life story of a person from all the perspectives; memoir mainly revolves around the turning points, the main events, the basic and influential memories and moments in a person's life. Satrapi turns to the graphic memoir to capture the most important moments and situations in her life and in her country's history.

The ultimate goal of Satrapi's memoir is to fight forgetting. It is known that "the struggle of man against power is the struggle of memory against forgetting" (qtd. in Rumnong 13). This reflects a human desire, as each person works on making others remember him through creating precious and valuable moments. Thus, one will always be alive even after his death. In her introduction to Persepolis, Satrapi writes that she does not want those Iranians "who lost their lives in prisons defending freedom, who died in the war against Iraq, who suffered under various repressive regimes, or who were forced to leave their families and flee their homeland, to be forgotten. One can forgive but one should never forget" (2). The role of memory, as a recurring theme is reinforced, not only by Satrapi herself, but also by her uncle, Anoosh who narrates his story of exile and imprisonment to Satrapi. The goal of his narration (see fig. 1) is to save the memory of their family from being lost forever

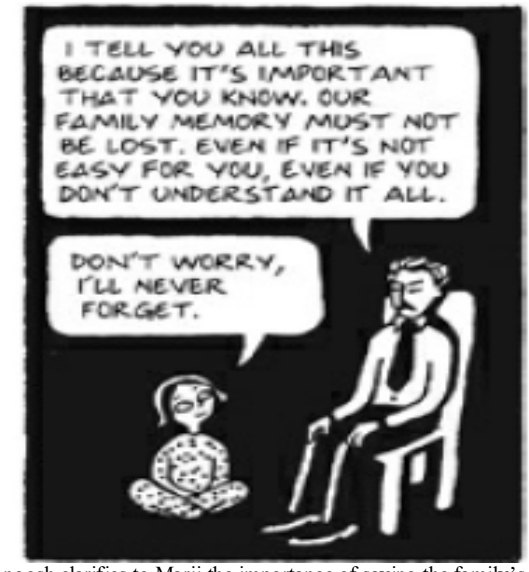

Fig. 1. Ancle Anoosh clarifies to Marji the importance of saving the family's memory

From Marjane Satrapi, The Complete Persepolis, New York, Pantheon Books, 2007, 64. 


\section{The Traumatic Memory}

One characteristic of trauma is its episodic memory. Unlike any ordinary memory, the episodic memory "is highly emotionally charged and stays in an activated, primed state without being integrated with other memories" (Hwangbo 3). Being a traumatic person who lives in a traumatic society, Satrapi has this kind of episodic memory. This is clear in Persepolis, as Satrapi divides her graphic novel into episodes; each of which reflects a memory, such as "The Veil" "The Bicycle" "The Water Cell" "Persepolis" "The Letter" among others. This episodic structure invites the reader to read each memory individually to appreciate it, then to put these separate memories together to make her story coherent and to gain a perception of her memories in general and her trauma in particular.

Any reader may question the truth and validity of Satrapi's memories and may also find a problem in fully trusting them because most of these memories are recalled from her childhood. Memory is not an authoritative psychological element, since it can be "contaminated not merely by gaps, but by distortions and fabrications that inevitably creep into it" (Yagoda 103). It seems unusual to remember complete scenes from your childhood and to give detailed depictions of them. Yet, Satrapi's memory is unlike the memory of any ordinary person; it is a traumatized memory. The traumatized memory is characterized by its strength and precision, as traumatic events are carved powerfully and strongly within them. While the ordinary memory is subject to mistakes and forgetting, the traumatized memory is unique because the more intensive an event is the better one remembers it. Werner Bohleber illustrates:

The precision of a memory is often directly proportional to the emotional excitation caused by an event. The emotional intensity ... as well as the surprise element and general consequence of an event, are key determinants. Experiences that are characterized in this way can be remembered for longer periods with great precision and in more detail. (336)

Historical trauma is closely associated with memories. History fights to rewrite itself "through the direction of memory-and traumatic memory in particular" (Radstone 21 ). Traumatic memory is arisen because of the unwillingness of the traumatic person to confront traumatic events. Due to the devastating impact of traumatic memories, the traumatized person begins to suppress them unconsciously:

Because the [traumatic] memories are painful and unmanageable, the conscious personality wishes to banish them from awareness (suppression). Once the banished memories have entered the second consciousness, the conscious personality gradually loses access to them, as an act of self defense, and this makes healing a complex process. (Young 37)

According to Freud, traumatic memories enter the second consciousness phase where they hide and become inaccessible. They become as secrets that are isolated from the conscious personality.

\section{Ways of Healing Traumatic Memory}

In order to overcome a traumatized memory, one has to come face to face with it through remembering. Remembering can "fill in gaps in memory ... to overcome resistances due to repression" (Freud, "Rememering" 148). Satrapi tries to fill in the gaps by making a 
conversation with her young self, which she called, Marji; a nickname of Marjane. This form of addressing herself through her young version, Marji, enables Satrapi to overcome the tragic memories connected to her painful traumas. Satrapi decides to pay a visit to her past through remembering. Remembering is the first step in healing the traumatic memory and in gaining its normal form again. Bohleber mentions that Freud viewed the traumatic memory as, "a foreign body in the psychic tissue that ... loses its foreign body structure through an effective remembrance" (338). Only through this confrontation, one will realize that what haunts him is a mere, "reflection of a forgotten past" (Freud, "Beyond the Pleasure" 13), so one has to put it aside. Freud calls this action of facing your memories, "a triumph for the treatment ... through the work of remembering" ("Remembering" 153).

Following the act of remembering, narrating the traumatic past is a more developed stage in the healing process. Narration can contribute to burying these traumatic and repressed memories forever and to reaching a kind of reconciliation between one's painful past and his disturbed present. This action of narration can gradually, "unravel the traumatic knot" (Hwangbo 97). By confessing his trauma through narration, the traumatized person can find relief; since he decides to expand his experience beyond his mere self by making others share him his trauma. After narration, the traumatized memory begins to be transformed gradually into an ordinary one.

Satrapi decides to bravely confront her traumatic memories by narrating them. Persepolis ends with Marji's departure to France to join the School of Decorative Arts. After settling in France, Satrapi finds herself facing two hard choices: whether to spend her entire future life trapped in that traumatic past or to move on and create a better future. She decides to free herself from the chains of her past, to figuratively unveil her memories, to disclose her secrets so as to remove their chronic scars from her life. Writing her story as a memoir is wise since memoir gives "silent speakers and victims the space to articulate" (Nayar 64). Any person usually finds relief and reassurance in confessing his/her dark secrets to close people. By writing Persepolis, Satrapi reaches the utmost degree of confession by choosing not to confess to just few close friends or family relative, but to the entire world. Narrating her story gives her "the courage to confront the past, reexamine it, retell it, and thereby to remaster its traumatic aspects" (Brison 49). She begins to reunite with her past by expressing it visually and verbally through the graphic medium.

Satire is another technique that Satrapi used as a form of healing her traumatic past and as a way to lessen the burden of historical trauma. In the chapter "The Joke", Satrapi writes, "the only way to bear the unbearable is to laugh at it" (269). When satire and humor are used in situations where seriousness is expected, this gives power to the work of art and decreases the weight of historical trauma and its heavy impact on the reader. Satrapi tries to "mask the seriousness of its statement under the guise of comic laughter" (Basu 5). Humor occurs due to surprise when a clash takes place between what is expected in mind and what is really happening. Satrapi uses satire in Persepolis as a tool of resistance against the state of dictatorship and oppression that Iran witnessed. For instance, Satrapi draws a humorous scene (see fig. 2) that depicts how children begin to use the veil at her school, as a play tool, since they have no idea of why they have to wear it. Here, children try to rebel against the compulsory orders. Though the panel seems humorous, it sends a harsh criticism of the dictatorship of Iran. Amy Malek writes, "Satrapi decided that humor was a way of dealing with pain in her life. She also uses humor to see readers through the most trying parts of her story" 
(372). Here, humor is used as two face coin: for fun and for criticism. Satrapi tries to prove that with all the traumas she has faced, she does not lose her sense of humor. She succeeds in conquering her traumas.

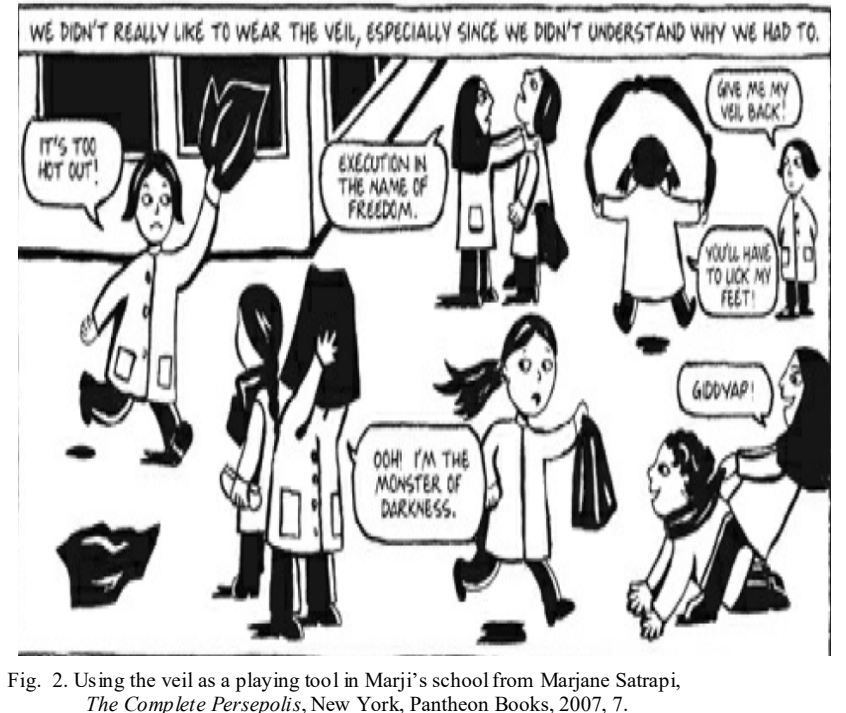

The Impact of Historical Trauma on Three Levels

In an attempt to comprehend the depth of historical traumas in Persepolis, it is essential to trace their impact on three levels: the individual (e.g. Marji), the family (e.g. Marji's family), and the community (e.g. the Iranian community). Maria Yellow Horse Brave Heart was interested in "examining [historical] trauma and its impact" ("Wakiksuyapi" 246). While Brave Heart focused on historical trauma among Native Americans, the current paper applies Brave Heart's model of historical trauma to a different context, in relation to Persepolis. Such application can open the space for a wider and more comprehensive view of historical trauma and the way it influences all the angles of a traumatized society.

\section{On the Individual Level}

In order to have a closer look at the impact of historical trauma on the individual level, it is crucial to discuss the concept of HTR (historical trauma response). Through her research in the 1890 Wounded Knee Massacre, Brave Heart notices that there is a great result of this massacre on Native Americans. This result is what she termed HTR. Brave Heart defines HTR as, "a constellation of characteristics associated with massive cumulative group trauma" ("Gender Diffferences" 1). Symptoms of HTR include, as Brave Heart illustrated, "depression, suicide, and substance abuse" ("Gender Differences" 3) and in another article, Brave Heart adds, "self destructive behaviors" ("Wakiksuyapi" 247). In Persepolis, Marji is the victim of historical traumas that surrounded her. First, she finds herself trapped in Iran during the historical trauma of the Islamic revolution and the Iran-Iraq war. Then, these events forced her parents to send her away to Austria to be safe from the interior chaos. Thus, she comes face to face with the trauma of being a stranger in a foreign land. Finally, in order to escape the hell of living 
in Austria, she returns back to Iran. To her own surprise, she confronts the trauma of being a stranger in her homeland. Consequently, Marji experienced HTR and the accompanied features of it.

Depression and the subsequent drug abuse are two features of HTR that Marji experienced. She finds herself an alien among her foreign friends. Then, her boyfriend cheated on her. Her depression reached its utmost point when she felt shameful for not meeting her parents' great expectations of her. She lets them down. Her body becomes the site on which she inflicted danger and practiced selfpunishment. She begins to smoke cigarettes heavily, to take drugs, and even to sell them. Later on, she becomes broke, lives in the streets, and begins to search for food in the trash cans. She stays in the streets for many months during winter. She finally collapsed and moved to hospital. Despite her doctor's orders, she buys many cigarette packs. She tries to destruct herself physically. This is her way to escape her trauma. She explains this in Persepolis, saying, "I think that I preferred to put myself in serious danger rather than confront my shame. My shame at not having become someone. The shame of not having made my parents proud after all the sacrifices they had made for me. The shame of having become a mediocre nihilist" (247).

Marji's depression results in her suicide attempt. After returning back to Iran, she decides to remain silent by not revealing her previous secrets to her parents. This silence makes her unable to continue her life peacefully. Failing in confronting her past makes her lost with no clear identity. She cannot find her true self. Her present and future are blinded by her past. She is no longer that young Marji whom she left in Iran many years before. Nothing remains as she leaves it. Now, she has to be accustomed to the new Marji and the new Iran. Her inner trauma makes her confess, "my calamity could be summarized in one sentence: I was nothing. I was a westerner in Iran. An Iranian in the West. I had no identity. I didn't even know anymore why I was living" (Satrapi 275). This insecure sense of self results in Marji's decision to put an end to her life. Marji's suicide attempt is a logical result of what Brave Heart calls unresolved grief of trauma. It is the "impaired or delayed mourning that is part of the experience of massive loss" "Gender Differences" 3). Marji commits several attempts of suicide. She tries to cut her wrest by a knife, but her fear of blood makes her use a fruit knife (Satrapi 275). Thus, her injury is not serious. After this failed attempt, she swallows all her anti-depressive pills (Satrapi 276). Yet, these pills do not kill her. They only result is three days of deep sleep and hallucinations. After these failed attempts of suicide, Marji concluded, "I was not made to die" (Satrapi 276). From that time, Marji's life begins to take a new turn. Marji starts a new stage in her development; her physical transformation.

In her search for her lost identity, Marji uses her outside appearance as a tool to heal her trauma and to start over. She changes the style of her clothes, her shoes, her makeup, and her hair. She finally becomes a completely different person than before (see fig. 3 ). She is unaware that all these changes are superficial and have nothing to do with healing her traumatic scars or her torn inner self. They are from outside, not from the inside. These changes only facilitate her marriage which ends in divorce, due to compatibility problems. Marji comments on this marriage saying, "in the space of two months, we went from weekly fights to daily insults" (322). Marji's inability to cope with anything around her results in her decision to leave Iran eventually and to head to France. Marji announces, "not having been able to build anything in my own country, I prepared to leave it once again" (342). 


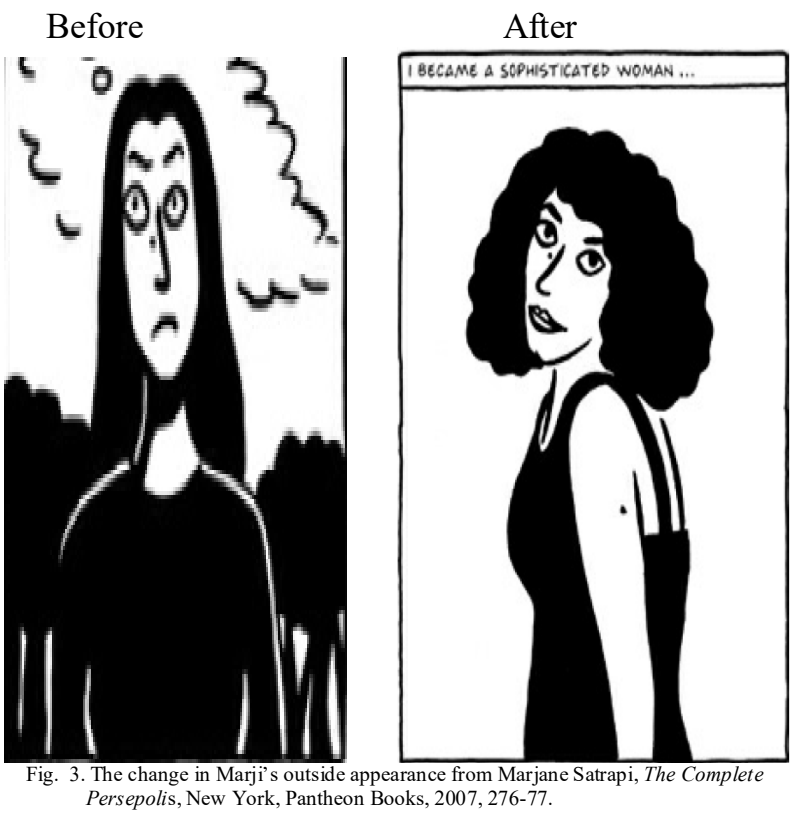

\section{On the Family Level}

One great consequence of historical trauma for both families and children is boarding schools. In addition to the massacre, Native Americans faced another trauma which is, "the placement of American Indian children in boarding schools; sometimes over 1,000 miles away from families and tribal communities" (Brave Heart "Wakiksuyapi" 246). Yet these schools have had devastating consequences. Brave Heart discusses some of these consequences in her article "The American Indian Holocaust", saying that these children are kept away from their families and communities for years, consequently, "some of them ... never returned to their homes and many died from disease and homesickness while in boarding schools" (63).

Similar to Native American families, Marji's family decides to send her to a boarding school in Austria. Marji is an only child. Sending her away is a dilemma; a tough decision that her family makes due to the circumstances in Iran that are moving from bad to worse. They sat with her and declared, "considering the person you are and the education you have received, we thought that it would be better if you left Iran" (Satrapi 151) and added, "we love you so much that we want you to go ... judging by the situation here, you'll be better off somewhere else" (Satrapi 152). The scene at the airport is tragic. Her parents are in a great grief. Satrapi depicts the reaction of Marji's parents and the fainting of her mother (see fig. 4). The father carries the fainted mother in a clear reflection of how historical trauma separates the unity and destroys the essence of the family. Besides Marji's family, several other Iranian families suffer from the same fate. They also have to send their children away to be safe. Marji's aunt and her husband also send their oldest son to Holland. Marji's father comments on this, saying, "can you imagine? A thirteen-fourteen-year-old child alone in a country where he does not even speak the language" (Satrapi 123). His comment can be related to all other Iranian kids who are victims of political unrest. 




Fig. 4. The scene at the airport from Marjane Satrapi, The Complete Persepolis, New York, Pantheon Books, 2007, 157.

Not only does the family suffer, children abroad and in boarding schools are not better cases. Marji, for instance, also leads a tough life in the boarding school. Like the Native American kids who were treated as inferior in boarding schools and faced several persecutions, Marji also faced tough times in the boarding school. In the chapter called "Pasta", Marji describes an insult that she receives from the nuns in her boarding school, when she decides to go and watch TV in the refectory and takes a pot of pasta with her. She is too hungry to take just a plate of pasta. The nuns in the school blame Marji for this behavior, but their insult is not addressed only to Marji, but to all Iranians: "it's true what they say about Iranians. They have no education" (Satrapi 180). In another situation, some girls insult her too. They called her an ugly girl with a cow-like face. They believe that being in a boarding school means that "her parents clearly don't care about her or they wouldn't send her alone" (199). 


\section{On the Community Level}

Boarding schools' impact spreads to include not only families and children, but also the entire community. These schools threaten the existence of native traditions and customs and lead to the breakdown and collapse of traditional values. This is because children who join them usually have to abandon their traditional habits, cultures, and their native language so as to sink in the other nation's life. Brave Heart mentions this impact saying, "spiritually and emotionally, the children were bereft of culturally integrated behaviors that led to ... a solid American Indian identity" ("The American Indian Holocaust" 64). These children are forced to quit their native manners to be welcomed in the other country's world. In Persepolis, Marji's parents are aware of the role of boarding schools in depriving the person from his roots. Thus, the first advice of Marji's father to her is "don't ever forget who you are" (Satrapi 152). Marji's father is right because Marji fails to keep her Iranian identity in Austria. She tries to bridge the gap between her culture and her friends' culture by adopting their identity. Even this behavior does not reserve a place for her among her foreign friends. Marji hears some foreign girls attack her. One of them says, "she [Marji] told my brother that she was French . . . she never talks about either her country or her parents" (Satrapi 199). Only then, Marji expresses her anger and reveals her true Iranian nationality saying, "you are going to shut up or I am going to make you! I am Iranian and proud of it" (Satrapi 200). It is only under pressure that Marji decides to declare her nationality.

The seriousness of historical trauma appears in changing every aspect of life in the traumatized community. The Islamic revolution, for instance, altered the face of the Iranian community. All bilingual schools and universities are closed for two years. One of the religious leaders justifies this action saying, "the education system and what is written in school books ... are decadent. Everything needs to be revised to ensure that our children are not led astray from the true path of Islam" (Satrapi 77). This oppression extends to strangle every kind of freedom. In streets, for instance, the presence of the Guardians of Revolution is a clear example of controlling the freedom of wearing what one wants. These guardians, as Marji asserts, are assigned to, "arrest women who were improperly veiled" (Satrapi 136). If any woman is arrested, she will be taken to the committee, the head quarter of these guardians, where she will be beaten, "for hours or for days ... [She] could be whipped" (Satrapi 138).

The Iranian community before the Iran-Iraq war was not the same after this war. Upon returning back to Iran and wandering in the streets, Marji finds out that the original names of streets were replaced with the names of martyrs. She expresses this by drawing several skulls buried under her feet (see fig. 5), with the caption, "I felt as though I were walking through a cemetery" (254). This reflects the great number of people who died in war. In addition, the Iranian economy begins to suffer seriously. The Iranian currency lost its value. Marji says that during the Shah, "it was seven tumans to the dollar" but four years later, "it was 110 tumans to the dollar ... the change was so sudden" (Satrapi 142). 


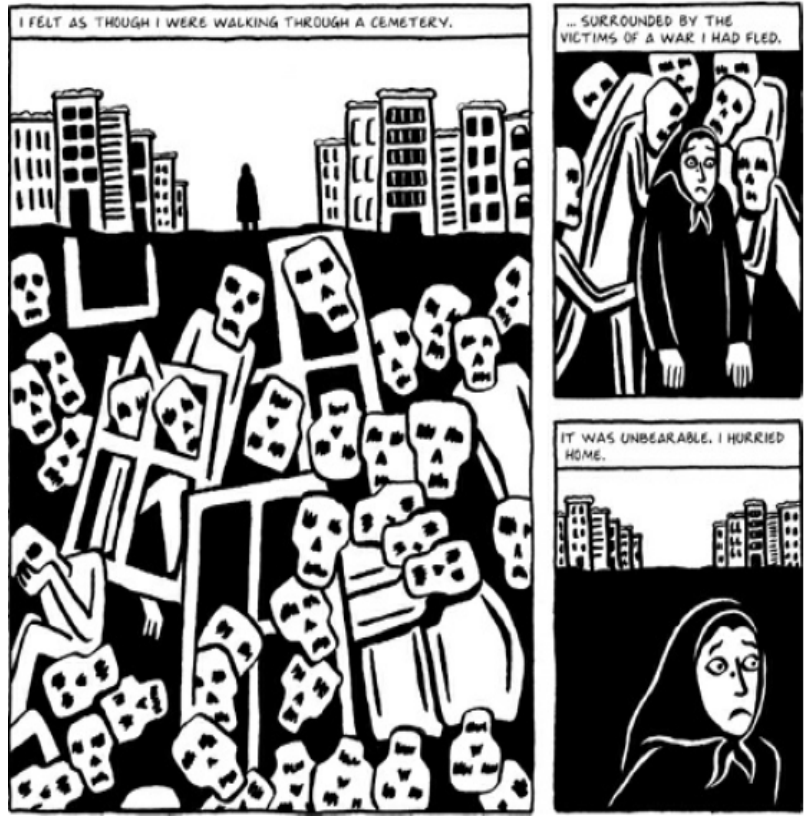

Fig. 5. The great number of martyrs due to the Iran-Iraq war from Marjane Satrapi, The Complete Persepolis, New York, Pantheon Books, 2007, 254.

\section{Conclusion}

Marjane Satrapi's Persepolis focuses on the traumatic atmosphere that dominates a certain stage in the history of Iran; especially the Iran-Iraq war and the Islamic revolution. Though Satrapi depends in her memoir on her traumatic memory, this kind of memories proves itself to be psychologically more meticulous than ordinary memory. It is a highly detailed memory that is armed by the emotional burden of trauma on a person. In addition, it is revealed that remembering and narrating trauma are two strategies of healing traumatic scars. Using satire in some situations helps Satrapi in retaining a sense of authority over her surroundings and in overcoming her traumas. Historical trauma has profound impacts on the individual, the family, and the community in a traumatized society. Revealing these impacts helps in having a closer look at the devastating consequences of historical trauma and the way it functions.

Through Persepolis, this paper explores how the graphic novel has matured as a profound medium of art that reflects traumatic issues in a precise way through the word-image interplay. On the theoretical level, this study applies trauma theory to a non-western country, Iran. Trauma theory has always been concerned with the study of western events (e.g. WW1, WWII, Vietnam War, Holocaust, etc). Thus, its applicability to other regions is unusual. This paper divorces trauma theory from its western context by applying it to a Middle Eastern country so as to develop trauma theory and to show that the Middle East has its own share of trauma. 


\section{References}

Basu, Lopamudra. "Crossing Cultures / Crossing Genres: The ReInvention of the Graphic Memoir in Persepolis and Persepolis 2." Nebula 4.3 (2007): 1-19. Print.

Bohleber, Werner. "Remembrance, Trauma, and Collective Memory: The Battle for Memory in Psychoanalysis." IPA 88 (2007): 329-52. Print.

Brave Heart, Maria Yellow Horse. "Gender differences in the historical trauma response among the Lakota." Journal of Health and Social Policy 10.4 (1999): 1-21. Print.

---. "Wakiksuyapi: Carrying the Historical Trauma of the Lakota." Tulane Studies in Social Welfare 21-22 (2000): 245-266. Print.

Brave Heart, Maria Yellow Horse, and Lemyra M. DeBruyn. "The American Indian Holocaust: Healing Historical Unresolved Grief." American Indian and Alaska Native Mental Health Research 8.2 (1998): 60-82. Print.

Brison, Susan J. "Trauma Narratives and the Remaking of the Self." Acts of Memory: Cultural Recall in the Present. Ed. Mieke Bal, Jonathan Crew, and Leo Spitzer. NH: UP of New England, 1999. 39-54. Print.

Caruth, Cathy, ed. Trauma: Explorations in Memory. Baltimore: John Hopkins U P, 1995. Print.

Freud, Sigmund. "Beyond the Pleasure Principle.” Trans. James Strachey. SE 18 (1961): 1-68. Print.

---. “Remembering, Repeating, and Working Through.” Trans. Joan Riviere. SE 12 (1950): 147-156. Print.

Herman, Judith. Trauma and Recovery: The Aftermath of Violence from Domestic Abuse to Political Terror. New York: Basic Books, 1997. Print.

Hwangbo, kyeong. "Trauma, Narrative, and the Marginal Self in Selected Contemporary American Novels.” Diss. Florida U, 2004. Print.

Malek, Amy. "Memoir as Iranian Exile Cultural Production; A Case Study of Marjane Satrapi's Persepolis Series.” Iranian Studies 39.3 (2006): 353-380. Print.

Nayar, Pramod K. "The Visual Turn: Affect, Autobiography, History, and the Graphic Narrative." ICFAI University Journal of American Literature 2.3-4 (2009): 58-72. Print.

Radstone, Susannah. "Trauma Theory: Contexts, politics, Ethics." Paragraph 30.1 (2007): 9-29. Print. 
Rumnong, Daiarisa. "The Struggle of Memory against Forgetting: An Analysis of Persepolis." Journal Of Humanities And Social Science 20.4 (Apr. 2015):13-15. Print.

Satrapi, Marjane, writer and artist. The Complete Persepolis. Trans. Mattias Ripa and Blake Ferris. New York: Pantheon Books, 2007. Print.

Yagoda, Ben. Memoir: a history. New York: Riverhead Books, 2009. Print.

Young, Allan. The Harmony of Illusions: Inventing Post-Traumatic Stress Disorder. New Jersey: Princeton U P; 1995. Print. 
"تجسيد المعاناة التاريخية في الرواية المصورة برسبوليس للكاتبة مرجان ساترابي "

الباحثّة/ إيمان محم عبد الحميد إبراهيم

ملذص البحث باللغة العربية :-

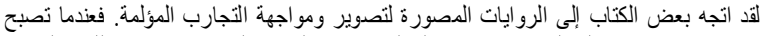

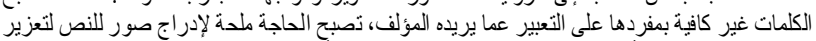

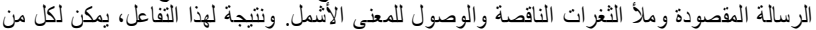

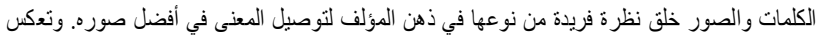

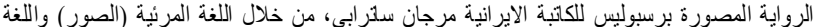

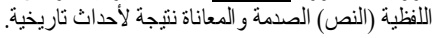

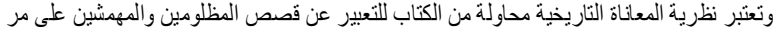

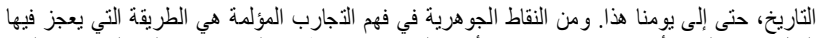



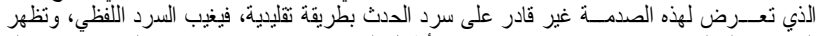

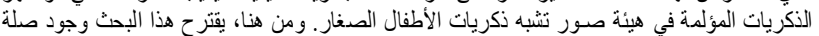

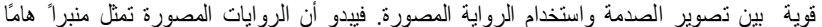



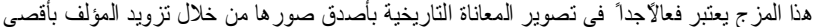

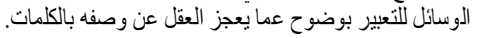

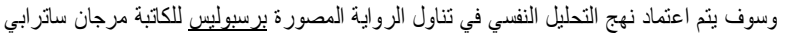

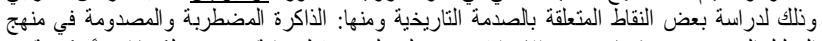

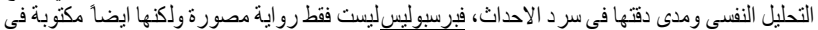

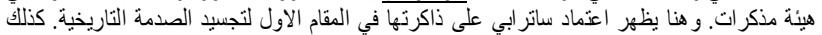



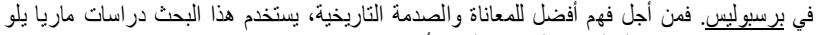

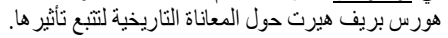



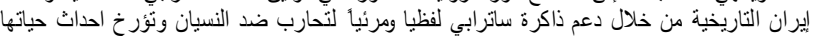

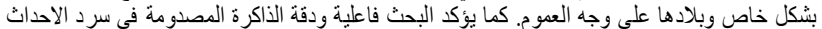

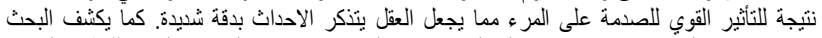

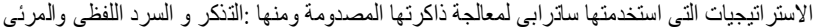

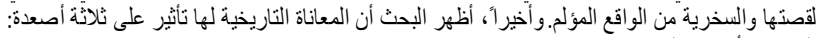

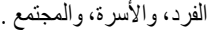

